\title{
Transformation of Thai Society: Critiquing American Imperialism through S.P. Somtow's Jasmine Nights
}

\author{
Kittiphong Praphan
}

\begin{abstract}
The U.S. power had risen in Southeast Asia during the Indochina War which later developed to be the Vietnam War. While the Americans physically fought in Vietnam, other countries in this region were also affected by military activities and other issues associated with American Imperialism. The escalation of the war and the power contest between the superpowers brought about a myriad of changes in Southeast Asia, including Thailand. In Jasmine Nights, Somtow employs American Imperialism and the Vietnam War as the backdrop of the story, which portrays negative consequences of this domination in Thai society. The identities of the major characters are also constructed by American Imperialism. Through this paper, I argue that Jasmine Nights functions as a channel through which Somtow critiques American Imperialism by illustrating that the social and economic structures of Thailand is transformed by American people as well as the American government which tries to penetrate into this region for military, political, and economic advantages. This transformation gives way to capitalism to prosper and control the economy of the country, while the gap between the rich and the poor is widened, and the traditional way of life is altered. Somtow deploys this novel as a tool to create a postcolonial counter-discourse in order to give voice to and speak for Thai people - the so-call colonized subjects in the era of neocolonialism - to indicate that an important root of the social and economic transformation in Thailand is American Imperialism. In addition, this novel serves as a self-representation of Thai people who, under Western epistemic domination, lack power to represent themselves.
\end{abstract}

Index Terms-American imperialism, Asian American literature, postcolonial writing, social transformation.

\section{INTRODUCTION}

The United States is marked as one of the greatest Western countries exercising power in Southeast Asia, especially after World War II. After the end of this great war, traditional colonialism began to decline and Western colonizers gradually retreated to their countries. The United States, however, emerged as a new power to dominate this region in the form of imperialism or neocolonialism. As stated by Young, after 1945, direct colonialism and domination by Europeans was no longer tenable. Unfortunately, the independent countries encountered a new form of domination, which still prolongs capitalist exploitation. Young further explains that the term neocolonialism was introduced in 1961, the essence of which is that "the State which is subject to it, in

Manuscript received January 20, 2019; revised March 19, 2019. This work is part of the Ph.D. dissertation, Rice Culture, Buddhism, Wars, and Diaspora: Mutual Legacies in Heterogeneity in Southeast Asian American and Diasporic Literature of Indiana University of Pennsylvania, USA.

Kittiphong Praphan is with Department of Western Languages and Linguistics, Faculty of Humanities and Social Sciences, Mahasarakham University, Thailand (e-mail: kittiphong.p@msu.ac.th). theory, independent and has all the outward trappings of international sovereignty. In reality its economic system and thus political policy is directed from outside" [1]. In other words, neocolonialism refers to the ruling of the less powerful countries by another means, not by the direct rule with authority control like in the past. Instead, it comes in the form of economic, cultural, ideological, and political control, with the aim to maintain the benefit of transnational corporations and internal elites. Based on Gramsci's theory of hegemony, Young argues, "the colonist already established a cultural, ideological, economic, and political force to the colonized to consent" [1]. With this force, people in less powerful or poor countries allow the colonist in the new form of colonialism to control them. In fact, after the independence, the former colonized countries were not yet ready to fully govern themselves, due to the lengthy subjugation and institutionalization of colonial economic structures by the colonizers. Moreover, those colonizers still maintained their domination for the sake of global capitalist exploitation, which returned the interest to the mother country. It is clear that colonialism has developed itself as Ania Loomba contends, "modern colonialism did more than extract tribute, goods and wealth from the countries that it conquered-it restructured the economies of the latter, drawing them into a complex relationship with their own, so that there was a flow of human and natural resources between colonized and colonial countries" [2]. With their new forms of conquest, the colonizers reshape the colonies in several aspects, such as politics and governance, education, policies, and most importantly economics, in order to facilitate the exploitation. Therefore, in terms of oppression, subjugation, and exploitation, neocolonialism or imperialism does not much differ from traditional colonialism.

In Southeast Asia, it can be said that the United States has the greatest dominating power in the age of neocolonialism, based on the history regarding the World War II and the Vietnam War. Apart from that, the expansion of American transnational corporations and cultural domination are evident in several Southeast Asian American and diasporic writings. Thailand, in spite of the fact that it has never been colonized by any Western country, is also tremendously affected by American imperialism. As Said states in Culture and Imperialism, at present, "imperialism is not about soldiers and cannons, but about ideas, about forms, about image and imagining" [3]. This concept is related to the idea of representation he discusses in Orientalism. The colonization of ideas, forms, and image confers power on the imperialist. With the superiority in military, economic, and ideological aspects, the imperialist dominates the inferior countries, changing their social structures for the imperialist's interest [4]. The relations of power and 
domination between the United States, as a new imperialist, and Thailand, which instigate several changes in Thai society, are reflected in S.P. Somtow's Jasmine Nights, a novel set in the rising age of American imperialism. In fact, Somtow is a very interesting writer, as he was born to an aristocrat family in Thailand and sent to study in England. With great talent, he became very successful as a writer in the United States. Most of his works deal with fantasy and vampires. He won the World Fantasy Award for best novella in 2002 and several awards dedicated to horror fiction, and was nominated five Bram Stoker Awards. Besides his writing career, he is also a music composer and symphonic conductor.

As a literary analysis, this paper argues that Jasmine Nights serves as an arena where Somtow critiques American Imperialism, which transforms social and economic structures of Thailand. Such transformation paves the way for capitalism to prosper and control the economy. In addition, this novel is also employed as a postcolonial counter-discourse which gives voice to the Thais, the so-called colonized people, to speak for themselves and inscribe their own history.

\section{Portrayal of Vietnam WAR AND the AdVEnT OF AMERICANS IN THAILAND}

Jasmine Nights depicts stories of Justine, a 12-year-old, Thai boy born in the United States. His parents, who are CIA officers, send him back to live with his aristocratic relatives in Thailand, where he learns many dimensions of Thai society. Through Justine's experience, many aspects of Thailand during the 1960s are presented. Among the most important issues, Somtow includes the influence of American imperialism as a major element of this novel. Justine, the most important character in the novel, has a background involved with American imperialism, which is expanding its territory to Southeast Asia during the time setting in the story. The Vietnam War with American involvement forces Justine's parents to send him back to Thailand, since they, as CIA officers, have to leave him for important missions: "They're doing very important work. Very secret work. [...] They've had to be in disguise most of the time" [5]. This truth is concealed from Justine until the very end of the novel. He receives a deep impact from American imperialism, having to part from his parents and brave the unfamiliar world in Thailand by himself. In creating this plot, Somtow incorporates historical account of the Indochina War, in which the United States was closely involved with. During the 1960s, the United States deployed several troops into Southeast Asia, where American military bases were situated. Apart from the troops, several organizations, including the CIA, were sent to the war zone. In Laos, for example, thousands of Americans penetrated into the country: "CIA operatives, USAID bureaucrats, International Voluntary Services (IVS) volunteers, Air America pilots, Air Force ground technicians and Blue Berets [...]" [6]. The CIA, in particular, had an important mission to acquire and provide military as well as political intelligence for the U.S. Army. Based on this historical account in which CIA officers had to conceal their identities, Somtow hides the identity of Justine's parents from him and the readers until the end of the novel. Somtow is very creative in outlining this plot; he assigns the CIA to employ Justine's parents who are Thai to work as spies, since they can easily assimilate with people in Laos, Vietnam, or Cambodia, which are in the war theater. This plot also implies that to win the war and expand its imperial power, the United States employs several military strategies, even the secretive ones. The Indochina War affects not only people in the war zone but also those in neighboring countries. As can be seen through Justine's separation from his parents, American imperialism has a deep impact on a large number of Southeast Asian people, even though they are not directly involved with the Indochina War.

During the 1950s and 1960s, the American's attempt to win the war and policy of Communist containment brought a large number of American citizens into Thai society, including military officers, diplomats, and other officials, sometimes along with their families. Thailand housed several important military bases for the United States, and in July 1953, officially, "the US [sic] National Security Council proposed developing Thailand as an 'anti-communist bastion in order to extend US [sic] influence-and local acceptance of it-throughout the whole Southeast Asia" [7]. After this establishment, the number of American troops in Thailand increased to 10,000 in 1962 and reached 45,000 in 1969. It is also stated that "The first air strike on North Vietnam was flown from Thailand in December 1964" [7]. It is obvious that Thailand was among the most important hubs of U.S. military bases in Southeast Asia, although this country was not directly involved with the Indochina War. The establishment of Thailand as an anti-communist bastion showed that the United States was dominating the political affair and foreign policy of the Thai government, which consented to facilitate the military mission of the United States, since the Thai could not possibly resist the American superpower.

The coming of Americans as a consequence of these military and political affairs is also pictured in Jasmine Nights. Besides military officers, American civilians also come to Thailand as their dependents or other important professionals. Virgil, another important character, along with his mother, and his sister-all are African American-has to follow his father, an American military officer, to Thailand. While his father is in the battle in Vietnam, Virgil and the rest of the family stay in Bangkok. Being introduced to Justine's aunts, Virgil explains in his black vernacular, "My father a military advisor. He a air force colonel. He in Saigon now" [5]. The coming of Americans exposes Thai people to those of other races, increasing ethnic diversity in Thai society. Being African American, Virgil's family is exotic in Thailand. The novel indicates that during that time, there are very few African Americans in the country. Most Thais have not yet seen people with the Black race before, so when the aunts first see Virgil with completely black skin, they are so startled that one of them exclaims in Thai, "My word! I've never seen one up close before. Do you think he'll bite?" [5]. As can be seen through this encounter, Somtow employs humor to deal with the racial issue in his novel. In fact, as members of the aristocrat, the aunts are familiar with white Americans coming to Thailand for military missions or for 
other professions, such as doctors or ambassadors. One of the American doctors also serves as a family doctor for the aunts. However, African Americans are still very rare in Thai society, so the presence of Virgil causes an astounding feeling to them. Apart from Virgil's family, there are also other minor American characters, such as the white American boys and their families who are racist against Virgil. Justine is the only one boy who accepts him as a friend. As evident in the historical account and the depiction of the Americans in Jasmine Nights, American imperialism dramatically increases the American populace in Thailand.

\section{TRANSFORMATION OF THAI SOCIETY}

According to the history, the advent of Americans inflicted several changes on Thai society in many aspects: "The city changed in shape, style, and taste. New suburbs clustered around the schools, shops, cinemas, and club catering for westerners. Elite Thai families were attracted to the same areas because of their perceived status and their rising property values" [7]. These changes served not only the needs of Westerners and Thai elites, but also the development of private capitalists pushed by American imperialism. New kinds of business, such as "bars, nightclubs, brothels, and massage palours" were established especially on the "American strip," a road in Bangkok, since Thailand was “chosen for the GIs' R\&R ('rest and recreation') tours" [7]. Bangkok became a major place for American soldiers and officials to take vacation from the battle in the war zone, attracting a large sum of U.S. dollars to Thai economy each year during that era. In spite of the flourishing economy, these businesses, in some ways, introduced degraded American values to Thai society. Thai people were introduced to nightclubs and bars increasing alcohol consumption in Thai society. The Thai elite, perceived these values as Western superior culture, adopted them as part of their lifestyles. In addition, they spent an extravagant life, such as partying and joining expensive foreign clubs, since they viewed these activities as ways to show off their high social and economic status.

The adoption of American lifestyles and values by the Thai elite is also vividly portrayed in Jasmine Nights, as can be seen through Justine and his aunts, who belong to the elite class. For instance, they go a cinema to watch Cleopatra stared by Elizabeth Taylor and Richard Burton. In addition, they join the Sports Club, which is described as highly luxurious and extravagant in Western styles:

We sweep into the club like an animated Chagall, an eye-popping contrast to the off-white walls, the white uniforms, the white tablecloths of the dining room, the elegantly colonial rattan of the veranda sun-chairs. The only thing gaudier than our eccentric assemblage is the spectacular twenty-two bath all-you-can-eat buffet which seems to stretch as far as the eye can see. There are hams, joints of beef, turkeys, pastries, assorted Siamese dishes, vegetables of every conceivable ilk, and an ice-cream sculpture as tall as myself, in the shape of a recumbent swan. There are rock lobsters on beds of lettuce, pates, cheese and fruits. The muffled soundtrack of a Bugs Bunny cartoon, being screened in some inner room to entertain the younger children while their parents are golfing, provides a kind of chamber music to accompany our repast. [5]

As can be seen through the excerpt above, Americans bring their culture into Thai society, including food culture, Western decoration style, popular culture, and sports. In addition, as portrayed in another scene, American fashion-with Jacqueline Kennedy as a model who always appears at the front pages of newspapers and magazines-greatly influences the ways high-class Thai ladies dress up themselves. Even Samlee, a servant who upgrades herself as a mistress of Justin's uncle, also dresses up and puts on makeup in American style: "She has a Cleopatra hairdo. She has shocking pink lipstick and rouged cheeks, above which she sports a pair of gilt-edged dark glasses. She wears a floral sundress and one of those hats popularized by Jacqueline Kennedy" [5]. The extravagant life and Western costume and makeup adopted by Samlee and other Thai elites are considered an imitation. Those Thai people view American imperialist culture as superior and more civilized and want to adopt it. This can be described by Said's concept of power of representation in which the West employs "a whole set of forces," such as military, knowledge, and politics, to create itself as superior to the East [4: p. 203]. In Thailand, although the U.S. army does not physically harm the country, it represents enormous military force. Moreover, as shown in the novel, the American seems to dominate Thai mass media and use them as tools in representing themselves and their culture. This can be seen through "the Sunday edition of Bangkok Post, which has a picture of Jacqueline Kennedy on the front page" [5]. Being the first lady of the United States as the superpower during that time, Jacqueline represents power, elegance, and modern civilization. As Thai ladies see themselves as inferior, they employ imitation as a means for themselves, who desire to be like or to be the same as superior American ladies, to uplift their appearance. The imitation of Western lifestyle by Thai people can be described by the concept of mimicry as discussed by Bhabha in his study about postcoloniality. Viewing the Western culture as a representation of power, people in the colonized countries try to adopt it and imitate the Western way of life in many aspects, such as costume, eating culture, and social behavior, in order to be like Western people. Nevertheless, Bhabha argues that although they try very hard to copy western people, it is impossible to be completely the same, as he states, "almost the same but not quite" [8]. Based on this concept, no matter how hard the Thai upper-class people try to imitate the American way of life, they can never transform themselves to be completely like the Americans.

Due to the high cost of the above Western cultures, only elite, wealthy Thais are able to adopt them. For the poor, who are the majority of the country, these extravagant cultures are beyond their imagination. In the novel, Somtow also emphasizes this social contrast. While the rich are playing golf in the club's golf course or swimming in the club's pool, a lot more people are swimming in a klong, or a canal, just next to the club. While the rich are dining in luxurious restaurants, the poor are eating from street venders. These 
different lifestyles indicate a huge gap between the rich and the poor in Thai society. This gap is also widened by American imperialism, which espouses the development of capitalism. According to the history, American imperialism helped capitalists and the elite to increase their wealth by transforming traditional agriculture into agribusiness. However, farmers still struggled with poverty, since "they needed to buy seeds, fertilizers, and pesticides, and perhaps hire equipment for land preparation and harvesting" [7]. Although agribusiness increased the products, it demanded a larger investment. It turned out that after paying all production expenses, farmers obtained less surplus causing them to be overwhelmed by debt. The contrast between the rich and the poor contradicted the mission of development proposed by the American, as it was proved to be merely uneven development which helped only the rich to be richer and able to spend an extravagant life as illustrated above. In contrast, the poor still struggled for subsistence, since their surplus was appropriated by the rich through the production costs.

\section{The Flourishing OF Prostitution AND OTHER BUSINESSES}

As depicted in Jasmine Nights, another serious social degradation is inflicted on Thailand; American imperialism promotes prostitution in Thai society. This immoral business extremely flourishes during the time setting of the novel. Brothels are openly operated especially to attract foreigners, Americans in particular. As young boys in their transition to the teenage, Justin and his American friends desire for sexual experience. Their desire leads them to a brothel district in Bangkok, where GIs love to visit for their recreation, as Wilbur, one of the boys explains, "I've heard my dad talk about them [the brothels]. They're R and R places" [5]. As discussed earlier, "R and R" refers to "rest and recreation," so those places are especially established for American soldiers and officials to unwind from their duties. Justin describes the scene in a brothel where he and his friends visit as following:

Seated at the tables in the room are about a dozen male farangs [a Thai word for Westerners], many in military uniforms. Mostly they are alone or in pairs. Each one has a drink in front of him, which he is ignoring. Each one has a hostess, scantily clad, who is making eyes at, massaging or attempting to converse with him. Some of the women wear rabbit-ears, others have little helmets that resemble the heads of cats. They are all heavily made up, but some are little older than ourselves. [5]

As reflected in this novel, the increase of prostitution is an important change in Thai social structure, since it becomes prosperous business generating huge income for particular groups of people. The rising of this immoral business also indicates that money becomes an important factor for survival in the changing socio-economic condition. A lot of Thai women have to reduce themselves to prostitutes to gratify American soldiers' lust in order to earn money because the changing economy forces them. Agriculture under capitalism drives them into poverty, since they need to rely on capital for seeds, fertilizers, and other supplies.
Therefore, there are not a lot of choices for them to choose from. The last sentence of the above excerpt also reveals that teen prostitution also emerges in Thai society during this era. In fact, according to the Thai history, the number of prostitutes increased to approximately 300,000 in Bangkok during that period. Embarrassingly, "The interior minister, General Praphat Charusathian, wanted even more because they attracted tourists and boosted the economy" [7]. When American soldiers came to Thailand, they also spent their money on other things, not only on women. It is obvious that people in the governing class denied moral ethics and ignored the bad reputation of the nation as a consequence of prostitution, but aimed at only attracting money to the country. According to these changes, it can be said that Thailand was plagued by imperialism and capitalism, since money became prioritized in ruling the country. The Thai government even turned itself to be a capitalist appropriating the surplus generated by the prostitutes. This might be one of the facts that most Thai people want to ignore, although it really happened. It is an inconvenient truth about Thailand.

On the other side, as evinced in the novel, Americans, especially GI customers of the prostitution, view Thailand as a paradise for sexual indulgence and perceive Thai women as merely sex objects. Although this sexual exploitation happens in the period of the modern colonialism, it is similar to what happens during the traditional colonialism. In Joseph Conrad's classic novella, Heart of Darkness, this issue is also made visible through sexual exploitation of an indigenous woman by Kurtz, a Western colonist in Congo. He keeps her as his mistress, although he has already been engaged to a woman in his home country. This indigenous woman is viewed as only an object with no more value than a thing to gratify Kurtz's sexual desire [9]. In both two cases, traditional colonialism in Congo and modern colonialism in Thailand, therefore, the colonizers' perspectives toward colonized women are not different; they are viewed as only sources of sexual pleasure. As Said argues, the East, in particular, is represented through Western literature as a place that offers "the freedom of licentious sex" [4]. Sex in Thailand, as portrayed in Jasmine Nights, can be bought openly by money. Due to economic pressure instigated by American imperialism, a lot of Thai women have to walk into prostitution in order to survive the changing Thai economy and society. Compared to the traditional colonialism, the sexual exploitation of women in the age of American Imperialism is operated on a much larger scale, since it becomes a kind of business victimizing many more women. More terribly, instead of preventing prostitution, the ruling class supports it, viewing it as beneficial to the improvement of the nation's economy.

In addition to the reflection of the above social changes, Somtow also touches upon other issues regarding American imperialism. The next important phenomenon is that American corporations and business chains are introduced to Thai society. When Justin describes a canal beside his resident, he explains, "There will be s shopping plaza, a five-storied mall, a hotel, a McDonald's, a Pizza Hut, a condominium-in-progress" [5]. This depiction suggests that global capitalism has already expanded its territory into Thailand. This expansion will change lifestyles of Thai 
people, such as their recreational activities and their eating culture. They will spend their free time strolling around the shopping mall and consume American fast food. While they are enjoying these new cultures, the profit from these business chains is sent back to the mother country, the United States. This transaction is marked as an important socio-economic change influenced by neocolonialism. To promote the business, the Americans also employ their mass media in representing themselves. Magazines are examples of important American mass media brought into Thai society. American magazines also become indicators of high social status; Justin's aunts read Life magazines, while his Christian school subscribes to The Times. Supporting global capitalism, these social media function as channels for Americans to promote their image and business through both explicit and implicit advertisements, instilling American values into Thai subjects. Through Jasmine Nights, Somtow illustrates these changes in Thai society, instigated by American imperialism. These changes might be viewed as progress of development, but Thailand has to pay high prices to attain it.

\section{CONCLUSION}

American imperialism has greatly influenced people's life and society in Thailand. Although in some aspects, the dominating power moves the indigenous society towards development and modernity, the devastating effects of the colonial operation are incalculable. Jasmine Nights functions as a means to portray detrimental changes as a result of American imperialism in Thailand. This work gives a voice to the indigenous Thais, in order for them to represent themselves and inscribe their own history. During the colonial age, Thai people and Asian people as a whole were represented through Western knowledge constructed by Western imagination. According W.E.B. Du Bois' concept of double consciousness, they always see themselves "through the eye of others" [10], since they lack power to represent themselves. Those "others," or American power in this sense, creates the Thais under the influence of Orientalism, "a style of thought based upon an ontological and epistemological distinction made between 'the Orient' and (most of the time) 'the Occident" [4]. The epistemology of the Orient is imbued with politics which fosters European and American interest. The creation and portrayal of the Orient as opposite to the noble and civilized Occident are evident in Western "aesthetic, scholarly, economic, sociological, historical, and philosophical texts" [4]. The production of knowledge by the Occident makes the Orient visible to Westerners as well as to themselves, but they are visible in inferior ways. Therefore, the real purpose behind this production of Western knowledge is to justify the Western rule over the Eastern world for the sake of Western interest.

In terms of postcolonialism, although Thailand has never been officially colonized be Western countries, based on the concept above Thai people are constructed and represented through the colonial discourse inserted into a variety of texts as part of Western epistemology overshadowing the indigenous' self-representation. According to this concept, American people know about Thailand from what they have seen, read, or told in their country, such as the image of
Thailand as a place where they can indulge in sexual activities. This can be seen through Jasmine Nights, which indicates that Americans imagine Thailand a land for sexual pleasure. However, there are many more aspects about Thailand which they do not know. Or even for the sexual issue itself, there are various factors which cause Thai women to become prostitutes. To argue with Western epistemology, postcolonial writers "wish to speak for themselves, to tell their own stories, including the story of the colonial encounter and its consequences, and so to create the psychological base and historical understanding which will encourage wise choices in self-government" [11]. To free the colonial subjects from the colonial discourse, postcolonial literature also functions as a tool to represent the indigenous by themselves and to create the postcolonial counter-discourse. As stated by Tiffin, the postcolonial "counter-discursive strategies involve a mapping of the dominant discourse, a reading and exposing of its underlying assumptions, and the dis/mantling of these assumptions from the cross-cultural standpoint of the imperially subjectified 'local"' [12]. In other words, postcolonial writers, on their local standpoint, employ literature as an apparatus in arguing and refuting the Western knowledge on colonial subjects as well as the colonial world. In the case of Jasmine Nights, Somtow integrates postcolonial counter-discourse in his writing and produces knowledge about his world based on actual facts about his people and social circumstances. The epistemology in his work is independent from the politics underpinning the colonizer's interest, but it is built upon the interest of the indigenous people. In other words, Somtow critiques the politics of interest of the Americans under the concept of neocolonialism in his country through his novel.

Thais' lack of power to represent themselves can also be described by Spivak's concept about the voice of the marginalized. The term "subaltern" as defined by Spivak encompasses Southeast Asian people, especially the underprivileged or the marginalized who are outside the elite sphere. These people are silenced by the epistemological domination of the West, which Spivak calls "epistemic violence" [13]. The subaltern in this sense refers to "the margins (one can just as well say the silent, silenced center) of the circuit marked out by this epistemic violence, men and women among the illiterate peasantry, the tribals, the lowest strata of the urban subproletariat" [13]. In a similar fashion, San Juan also defines the subaltern as "subordinate populations oppressed by colonial/postcolonial regimes in various ways," such as political, economic, racial, and gender aspects [14]. In the colonial discourse, their voice is suppressed, so they are inevitably represented by the colonizer. Spivak poses the question, "Can the subaltern speak?" Of course, they can, but who will listen to them? The production of knowledge by the West-more directly the epistemic violence - suppresses their voice from being heard and recognized. Without voice, these people also seem to be invisible; their existence is denied. Therefore, it is the job of the intellectuals from the subaltern group to contend with Western epistemic violence, speak for their people, and make them visible in the society. Based on the representation of Thailand in Jasmine Nights, Somtow can be regarded as a Thai intellectual, being an important voice of Thai people and 
grappling with Western epistemological institutionalization. His work is marked as a production of Thai knowledge battling against the Western knowledge which suppresses the authentic voice of the Thais.

\section{REFERENCES}

[1] R. Young, Postcolonialism: An Historical Introduction, Massachusetts: Blackwell, 2001, pp. 45-46.

[2] A. Loomba, Colonialism/Postcolonialism, 2nd ed. London: Routledge, 2005, pp. 8-9.

[3] E. W. Said, Culture and Imperialism, New York: Vintage Books, 1994, pp. 6-7.

[4] E. W. Said, Orientalism. New York: Vintage Books, 2003.

[5] S. P. Somtow, Jasmine Nights, New York: A Wyatt Book for St. Martin's, 1995.

[6] F. Branfman, "Presidential war in Laos, 1964-1970," in Laos: War and Revolution, N. S. Adams and A. W. McCoy, Ed., New York: Harper Colophon Books, 1970, pp. 213-80.

[7] C. Baker and P. Phongpaichit, A History of Thailand. Cambridge: Cambridge UP, 2005.

[8] H. K. Bhabha, The Location of Culture, London: Routledge, 1997, pp. 86-88.

[9] J. Conrad, Heart of Darkness and Selected Short Fiction, New York: Barnes \& Nobel Classics, 2003, pp. 37-124.

[10] W. E. B. Du Bois, The Souls of Black Folk, H. L. Gates, Ed., Jr. New York: Oxford University Press, 2007, pp. 2-5.

[11] C.L. Innes, The Cambridge Introduction to Postcolonial Literatures in English, Cambridge: Cambridge University Press, 2007, pp. 4-5.

[12] H. Tiffin, "Post-colonial Literatures and Counter-discourse," in The Post-colonial Studies Reader, B. Ashcroft, G. Griffiths, and H. Tiffin. Eds., London: Routledge, 1995, pp. 95-98.
[13] G. C. Spivak, "Can the subaltern speak?" in The Post-Colonial Studies Reader, B. Ashcroft, G. Griffiths, and H. Tiffin., Eds. London: Routledge, 1995, pp. 24-28.

[14] E. S. Juan, Jr. Beyond Postcolonial Theory, New York: St. Martin's, 1998, pp. 85-87.

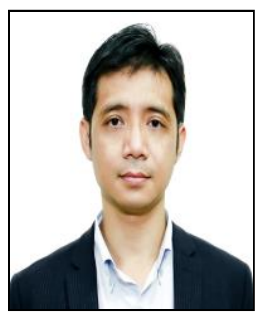

Kittiphong Praphan was born in Maha Sarakham, Thailand on August 5, 1976. He earned his bachelor's Degree (Hons.) in English from Mahasarakham University, Maha Sarakham in 1999, master's degree in English from Srinakharinwirot University, Bangkok in 2005, and doctoral degree in English: literature and criticism from Indiana University of Pennsylvania (IUP), PA, United States in 2015.

While pursuing his Ph.D., he worked as a teaching associate at Department of English, Faculty of Humanities and Social Sciences, IUP. He also worked as a research assistant to the Sustainable Studies Group in the same university. He published his first book, Introduction to Literature: Understanding Types, Forms, and Lives in English and American Literature through Intanin Press, Maha Sarakham in 2015. His research interest includes Asian diasporic and American literature, Postcolonial literature, and Postcolonial Ecocriticism.

Dr. Praphan is also a member of the network of translators for the Globalization of the Testimonies of Atomic Bomb Survivors, Japan. His dissertation, rice culture, Buddhism, wars, and diaspora: mutual legacies in heterogeneity in southeast Asian American and diasporic literature won an excellent graduate student research award at IUP in 2015. 